\title{
OUTCOMES FOR PATIENTS WITH SLOPING HEARING LOSS GIVEN STANDARD COCHLEAR IMPLANTS
}

\author{
Michelle Moran ${ }^{1,2,3}$, Richard C. Dowell ${ }^{1,2}$, Arielle Umansky ${ }^{3}$, Robert J.S. Briggs ${ }^{1,3}$, \\ Susannah Corbett ${ }^{1}$ \\ ${ }^{1}$ Department of Audiology and Speech Pathology, University of Melbourne, Melbourne, Victoria, Australia \\ ${ }^{2}$ HEARing Cooperative Research Centre, Melbourne, Victoria, Australia \\ ${ }^{3}$ Cochlear Implant Clinic, Royal Victorian Eye and Ear Hospital, Melbourne, Victoria, Australia
}

Corresponding author: Michelle Moran, Department of Audiology and Speech Pathology, University of

Melbourne, 550 Swanston Street, Parkville, Victoria 3010, Australia. Fax: +613 9347 9736. Phone: +613 9035 7996,

e-mail:mmoran@unimelb.edu.au

\begin{abstract}
Background: This study examined the speech perception outcomes for postlingually deafened adults using cochlear implants who preoperatively had steeply sloping hearing loss and in whom there was no attempt at electroacoustic stimulation. The aims were firstly to determine whether patients with sloping loss (SL) who received a standard-length cochlear implant electrode would show significant benefit; and secondly to compare the degree of benefit to a matched group of cochlear implant users with preoperative profound hearing loss.
\end{abstract}

Material and methods: A retrospective analysis of pre- and post-implant speech perception scores of 27 adults with sloping hearing loss and a matched group of 27 adults with profound hearing loss was conducted. Matching was based on age at implant and duration of loss. All were implanted with a Nucleus Freedom (CA) or a Nucleus 5 implant.

Results: Postoperative open-set speech perception testing demonstrated significant improvement compared to pre-implant for both groups. Speech perception outcomes were better in the SL group; however, there was no significant difference between the groups in the degree of improvement pre- to post-operatively under either the condition of implant alone or binaurally.

Conclusions: This study demonstrates that postlingually deafened adults with sloping hearing loss have the potential to gain significant benefit from cochlear implants, and achieve equivalent improvement in speech perception to implant recipients with profound loss. The results achieved in this group, without any attempt at hearing preservation, support the use of newer standard-length electrodes for both hearing preservation and optimal electric stimulation in patients with sloping hearing loss.

Keywords: cochlear implants • adults • hearing loss (high frequency)

\section{RESULTADOS DE LA APLICACIÓN DE LOS IMPLANTES COCLEARES ESTÁNDAR EN PACIENTES CON LA PÉRDIDA AUDITIVA CON LA CAÍDA EN LAS FRECUENCIAS}

\section{Resumen}

Introducción: El presente estudio valora los resultados del reconocimiento del habla en adultos con la pérdida auditiva postlingual, en las que antes de la inserción del implante coclear se pudo observar una pérdida auditiva con caída en las frecuencias agudas y en las que no se ha intentado aplicar la estimulación electroacústica. El primer objetivo ha sido el de comprobar, si la implantación del electrodo de la longitud estándar, es claramente beneficiosa para los pacientes con la pérdida auditiva con caída en las frecuencias agudas (SL). Se ha comparado, además, el grado de ventajas con el grupo de usuarios del implante coclear, en los que antes de la implantación se reconoció una pérdida auditiva severa.

Material y métodos: Se ha realizado un análisis retrospectivo de los resultados del reconocimiento del habla antes y después de la implantación, en 27 adultos con la pérdida auditiva con caída en las frecuencias agudas, y en otro grupo, también de 27 adultos, con la pérdida auditiva severa. En la selección de los participantes de la prueba se ha tenido en cuenta su edad en el momento de la implantación y la duración de la pérdida auditiva. En la prueba han participado los usuarios del implante Nucleus Freedom (CA) o de Nucleus 5.

Resultados: Las pruebas postoperatorias del reconocimiento del habla han demostrado una mejora significativa en comparación con los resultados de antes de la operación en ambos grupos. Los resultados de las pruebas han sido mejores en el grupo 
SL, sin embargo no hubo diferencia significativa en el grado de mejora antes y después de la implantación en ambos grupos con la inserción del implante en uno o en ambos oídos.

Conclusiones: El estudio demuestra que para los adultos con la pérdida auditiva postlingual, con la caída en las frecuencias agudas, los implantes cocleares pueden ser beneficiosos; estas personas pueden lograr una mejora similar en la comprensión del habla a la de las personas con una sordera severa. Los resultados obtenidos en ambos grupos, sin tratar de preservar la audición existente, son prueba para apoyar los beneficios que derivan del uso de los electrodos más modernos con una longitud estándar tanto en la preservación de la audición residual como y en la estimulación eléctrica óptima de los pacientes con caída en las frecuencias agudas.

Palabras clave: implantes cocleares • adultos • pérdida auditiva (para altas frecuencias)

\section{РЕЗУЛЬТАТЫ ИСПОЛЬЗОВАНИЯ СТАНДАРТНЫХ УЛИТКОВЫХ ИМПЛАНТАТОВ У ПАЦИЕНТОВ С НИСХОДЯЩЕЙ ТУГОУХОСТЬЮ}

\section{Изложение}

Введение: Настоящая работа оценивает результаты распознавания речи у взрослых людей с постлингвальной глухотой, у которых перед операцией кохлеарной имплантации наблюдалась круто нисходящая тугоухость, поэтому не было попыток применить електроакустическую стимуляцию. Первой целью являлось определение, является ли вживление электрода стандартной длины заметно полезным у пациентов с нисходящей тугоухостью (SL). Кроме того, сравнена степень пользы с группой пользователей улиткового имплантата, у которых перед операцией обнаружена глубокая тугоухость.

Материал и методы: Проведено ретроспективный анализ результатов распознавания речи перед и после имплантации у 27 взрослых людей с нисходящей тугоухостью и в другой группе 27 взрослых людей с глубокой тугоухостью. При отборе участников имел значение возраст во время имплантации и время продолжительности тугоухости. В исследовании взяли участие пользователи имплантата Nucleus Freedom (CA) или Nucleus 5.

Результаты: Послеоперационные тесты распознавания речи показали значительное улучшение в сравнении с предоперационными результатами в обеих группах. Результаты тестов были лучше в группе SL, однако не было значительной разницы в степени улучшения перед и после имплантации в обеих группах при использовании имплантата в одном или обоих ушах.

Итоги: Настоящая работа показывает, что взрослые люди с постлингвальной глухотой, с нисходящей тугоухостью имеют шансы на извлечение пользы из улитковых имплантатов, они могут получить подобное улучшение в понимании речи, как люди с глубокой тугоухостью. Результаты, полученные в обеих группах, без попыток сохранения существуюего слуха, являются свидетельством поддержки пользы, вытекающей из использования более современных электродов стандартной длины как при сохранении остатков слуха, так и при оптимальной электрической стимуляции у пациентов с нисходящей тугоухостью.

Ключевые слова: улитковые имплантаты • взрослые люди • тугоухость (для всех частот)

\section{WYNIKI ZASTOSOWANIA STANDARDOWYCH IMPLANTÓW ŚLIMAKOWYCH U PACJENTÓW Z OPADAJĄCYM NIEDOSŁUCHEM}

\section{Streszczenie}

Wprowadzenie: Niniejsza praca ocenia wyniki rozpoznawania mowy u osób dorosłych z głuchotą postlingwalną, u których przed zabiegiem implantacji ślimakowej zaobserwowano stromo opadający niedosłuch i nie próbowano zastosować stymulacji elektroakustycznej. Pierwszym celem było stwierdzenie czy wszczepienie elektrody o standardowej długości jest wyraźnie korzystne u pacjentów z opadającym niedosłuchem (SL). Ponadto, porównano stopień korzyści z grupą użytkowników implantu ślimakowego, u których przed zbiegiem stwierdzono głęboki niedosłuch.

Materiał i metody: Przeprowadzono analizę retrospektywną wyników rozpoznawania mowy przed i po implantacji u 27 osób dorosłych z opadającym niedosłuchem oraz u drugiej grupy 27 osób dorosłych z głębokim niedosłuchem. Przy doborze uczestników liczył się wiek podczas implantacji oraz czas trwania niedosłuchu. W badaniu udział wzięli użytkownicy implantu Nucleus Freedom (CA) lub Nucleus 5. 
Wyniki: Pooperacyjne testy rozpoznawania mowy wykazały znaczącą poprawę w porównaniu z wynikami przedoperacyjnymi w obu grupach. Rezultaty testów były lepsze w grupie SL, jednak nie było znaczącej różnicy w stopniu poprawy przed i po implantacji w obu grupach przy użyciu implantu w jednym lub dwóch uszach.

Wnioski: Praca wykazuje, że osoby dorosłe z głuchotą postlingwalną, z opadającym niedosłuchem mają szansę na czerpanie korzyści z implantów ślimakowych i mogą osiągnąć podobną poprawę w rozumieniu mowy jak osoby z głębokim niedosłuchem. Wyniki uzyskane w obu grupach, bez prób zachowania istniejącego słuchu, są dowodem na poparcie korzyści płynących z użycia nowszych elektrod o standardowej długości zarówno przy zachowywaniu resztek słuchowych jak i przy optymalnej stymulacji elektrycznej u pacjentów $\mathrm{z}$ opadającym niedosłuchem.

Słowa kluczowe: implanty ślimakowe • osoby dorosłe • niedosłuch (dla wysokich częstotliwości)

\section{Background}

High frequency or "sloping" sensorineural hearing loss is a common configuration of audiometric results in adults and can be caused by a number of etiologies including ageing (presbycusis), noise exposure, ototoxicity, and genetic factors. This type of hearing loss typically reduces the audibility of spectral cues of speech, in particular place of articulation cues for high frequency consonants, with subsequent negative effects on the clarity of speech $[1,2]$. Sloping hearing loss (SL), in which the hearing loss is mild to moderate in the low frequencies and severe to profound at $1 \mathrm{kHz}$ and above, can present a significant challenge for audiological rehabilitation. Conventional amplification may not always provide adequate benefit to patients with high frequency hearing loss, as issues such as feedback, recruitment, distortion, or cochlear dead regions can limit the effective programming of a hearing aid. Cochlear dead regions have been defined as regions in the cochlea where inner hair cells are non-functional and are prevalent in individuals with sensorineural hearing loss $[3,4]$. For clients with large or multiple dead regions, there are implications for the choice of hearing aid or amplification strategy [5]. In addition, increasing amplification in high frequency regions where the hearing loss exceeds $55 \mathrm{~dB}$ HL has been found to offer little to no improvement in speech perception performance, and can sometimes lead to a decrease in scores [6-8].

Frequency compression and frequency transposition hearing aids, which compress or transpose previously inaudible frequencies into less damaged regions of the cochlea, have been proposed as a possible solution for these individuals. Results in the literature on experimental outcomes have been mixed, with no clear consensus as yet on the benefits of frequency compression or transposition aids in individuals with SL [9-12]. The literature suggests that frequency compression or frequency transposition hearing aids may not be the ideal solution for individuals with a more severely sloping audiometric configuration. While Simpson et al. [10], Glista et al. [9], and Kuk et al. [12] have demonstrated improvements in speech recognition in groups with moderately sloping hearing losses, a study by Simpson et al. [11], looking specifically at listeners with severely sloping audiograms, demonstrated no measurable benefit with a frequency compression device in comparison to conventional amplification. It should be noted that the participants in this later study all had hearing levels above $1000 \mathrm{~Hz}$ in the profound range.
Electroacoustic stimulation (EAS), where a cochlear implant is used in combination with acoustic hearing, has been shown to provide significant benefits for suitable individuals [13-16]. Initial studies of EAS utilized a CI with an electrode array which, when inserted, does not extend as deeply into the cochlea as a standard length array. This has the benefits of an atraumatic insertion with minimal damage to apical intracochlear structures [17-19]. This design of electrode array provides electrical stimulation of the basal end of the cochlea while preserving the apical end to allow acoustic low frequency hearing post-operatively. However, patients with relatively poor acoustic thresholds in the low to mid frequencies may not benefit from this approach and rehabilitation options can be limited. With cochlear implant technology continually evolving, CIs for EAS have also evolved to include deeper cochlear insertions. While some studies have shown that residual hearing can be preserved through soft surgery and careful procedures with a standard length electrode array, the outcomes are variable [20-23].

Patients with severely sloping hearing loss tend to fall within a substantial 'grey area' in terms of management. The high frequency hearing in these patients is too poor to gain significant benefit from hearing aids and their low frequency hearing is too good to fit within standard cochlear implantation criteria; however the short electrode approach may not give the best outcome given the progressive nature of many of these types of hearing losses. In addition, many patients with a ski-slope audiometric configuration have poor speech perception despite optimal hearing aid fitting and so become standard candidates for cochlear implantation based on speech perception ability. CI technology has evolved to include devices such as the CI422 (Cochlear) and Flex28 (Med-El) which allow for the clinician and surgeon to attempt to preserve the residual hearing with a full-length electrode array and a soft surgery approach, which shows promise for patients falling into this group $[24,25]$.

Improvements in both CI technology and recipient outcomes have led to expansion in the candidacy criteria for cochlear implantation [26-28]. This in turn brings increased referral of patients with significant residual hearing. Patients with residual acoustic hearing have more to lose if their hearing is lost following CI surgery and their post-operative outcome for hearing with the CI does not meet expectations. Audiologists are presented with the clinical dilemma of weighing up the risk of losing the residual acoustic hearing versus the unpredictable amount of benefit to be gained by electrically stimulating the cochlea 
Table 1. Demographic data of the SL and PL matched groups

\begin{tabular}{|c|c|c|c|}
\hline & & $\begin{array}{l}\text { Sloping Loss group } \\
(n=27)\end{array}$ & $\begin{array}{l}\text { Profound Loss group } \\
(n=27)\end{array}$ \\
\hline \multirow{4}{*}{ Duration of deafness (years) } & Mean & 12.54 & 12.94 \\
\hline & SD & 8.94 & 9.82 \\
\hline & Median & 12.00 & 10.00 \\
\hline & Range & $1-34$ & $1-38$ \\
\hline \multirow{4}{*}{ Age at implant (years) } & Mean & 65.74 & 65.17 \\
\hline & SD & 13.84 & 12.68 \\
\hline & Median & 65.84 & 63.44 \\
\hline & Range & $35.23-89.27$ & $39.80-88.68$ \\
\hline \multirow{4}{*}{ 4FA $(\mathrm{dB})$ - ear to be implanted } & Mean & 96.48 & 117.50 \\
\hline & SD & 5.90 & 7.26 \\
\hline & Median & 96.25 & 120.00 \\
\hline & Range & $81.25-107.50$ & $102.50-125.00$ \\
\hline \multirow{4}{*}{ 4FA $(\mathrm{dB})$ - contralateral ear } & Mean & 89.77 & 103.29 \\
\hline & SD & 9.70 & 17.74 \\
\hline & Median & 91.25 & 105.00 \\
\hline & Range & $72.50-110.00$ & $57.50-125.00$ \\
\hline \multirow{4}{*}{$\begin{array}{l}\text { 4FA }(\mathrm{dB}) \text { - post-op hearing } \\
\text { (implanted ear) }\end{array}$} & Mean & $119.56(n=17)$ & $123.57(\boldsymbol{n}=7)$ \\
\hline & SD & 6.22 & 1.68 \\
\hline & Median & 122.50 & 123.75 \\
\hline & Range & $107.50-125.00$ & $121.25-125.00$ \\
\hline
\end{tabular}

using a CI. A recent systematic review examining studies that have investigated the preservation of residual acoustic hearing has demonstrated a significant speech perception benefit post-operatively using electric-only stimulation over their pre-operative scores [22]. The authors suggest that this provides evidence in support of attempting an electroacoustic device approach, as the recipients show benefit even where there is complete hearing loss.

The purpose of the present study is to examine the outcomes for a group of postlingually deafened adults with significant pre-operative residual hearing in the sloping loss configuration (SL group) whose pre-operative speech perception places them as candidates for a cochlear implant; however these subjects were not considered candidates for a hearing preservation approach using a short electrode. The results of the SL group, whose hearing was not preserved through CI surgery, will be compared to both their own pre-operative results and to a reference group of CI recipients with pre-operative profound hearing loss. The aim of the paper is to assess the degree of benefit received by electrically stimulating the cochlea of recipients with pre-operative sloping hearing loss, in comparison to the traditional CI patient with profound bilateral hearing loss.

\section{Material and methods}

To examine the impact of pre-operative SL on outcomes in adult cochlear implant recipients implanted with standard electrode arrays, a retrospective analysis was conducted from a database of 640 adults implanted at the Melbourne Cochlear Implant Clinic at the Royal Victorian Eye and Ear Hospital between September 2005 and July 2011. This research was conducted under the approval of the Royal Victorian Eye and Ear Hospital Human Research Ethics Committee (approval number 04/564).

\section{Subjects}

Subjects were selected for inclusion in this study based on their pre-operative pure tone audiometry results. Recipients were considered to have an SL when the audiometric thresholds of the ear to be implanted fell within the following range:

- $250 \mathrm{~Hz}$ and $500 \mathrm{~Hz}$ pure tone thresholds of $60 \mathrm{~dB} \mathrm{HL}$ or better

- $1 \mathrm{kHz}$ pure tone threshold of $75 \mathrm{~dB}$ HL or greater

- $2-8 \mathrm{kHz}$ pure tone thresholds of $90 \mathrm{~dB} \mathrm{HL}$ or greater.

These audiometric criteria were used in order to ensure the subject group had residual low frequency hearing but 

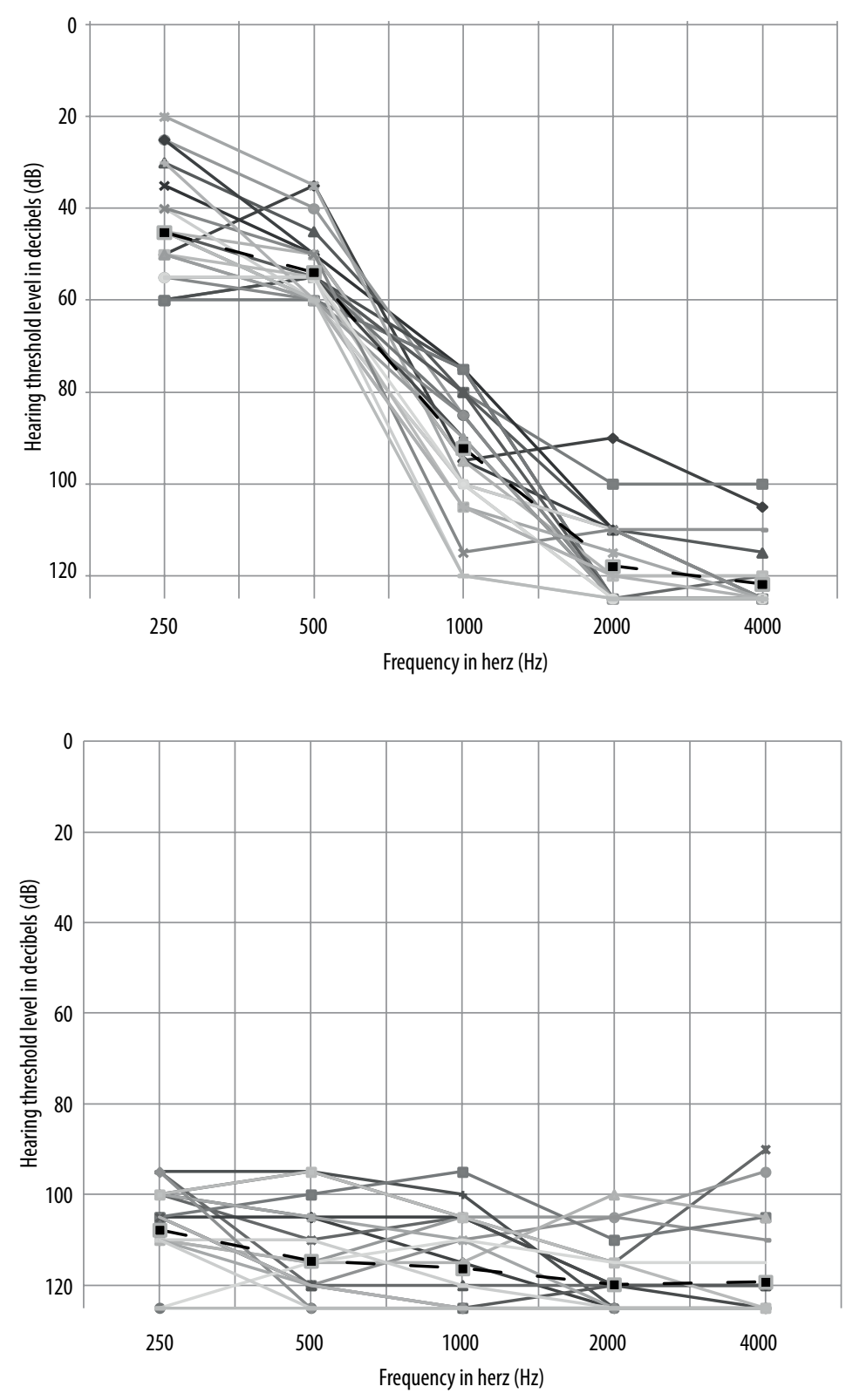

Figure 1. Hearing levels for each participant in the SL group. The group average is shown with black squares and dotted line

Figure 2. Hearing levels for each participant in the PL group. The group average is shown with black squares and dotted line no significant high frequency hearing. The criteria for 1 $\mathrm{kHz}$ was used given the clinical criteria at the time for attempting a hearing preservation technique using a short electrode, which required a $1 \mathrm{kHz}$ pure tone threshold of $70 \mathrm{~dB} H \mathrm{HL}$ or better. It must be noted that while these subjects were selected for a standard-length Contour electrode, with the range of devices available today they would likely be selected for a full-length array which could potentially preserve the low frequency hearing.

Subjects were excluded from the analysis if they were considered to have a prelingual hearing loss, if they underwent re-implantation, if English was not their first language, or if they were fitted with a short electrode device for EAS. Only recipients with unilateral cochlear implants were included in the analysis. A total of 27 recipients fitted the criteria.
A matched group of 27 recipients with pre-operative hearing in the profound range was selected for comparison. This profound loss (PL) group was matched with the SL group for both duration of deafness and age at implant. Each recipient in this matched group met the same inclusion criteria for the study as the SL group, only differing in their audiometric thresholds. More specifically, for the PL group the ear to be implanted was required to have thresholds greater than or equal to $90 \mathrm{~dB}$ from 250 $\mathrm{Hz}$ to $4000 \mathrm{~Hz}$.

The demographics of both groups are set out in Table 1. Audiometric thresholds of both groups are shown in Figures 1 and 2.

\section{Test materials}

An analysis of the pre- and post-implant speech perception scores of the SL group and the PL group was conducted. 

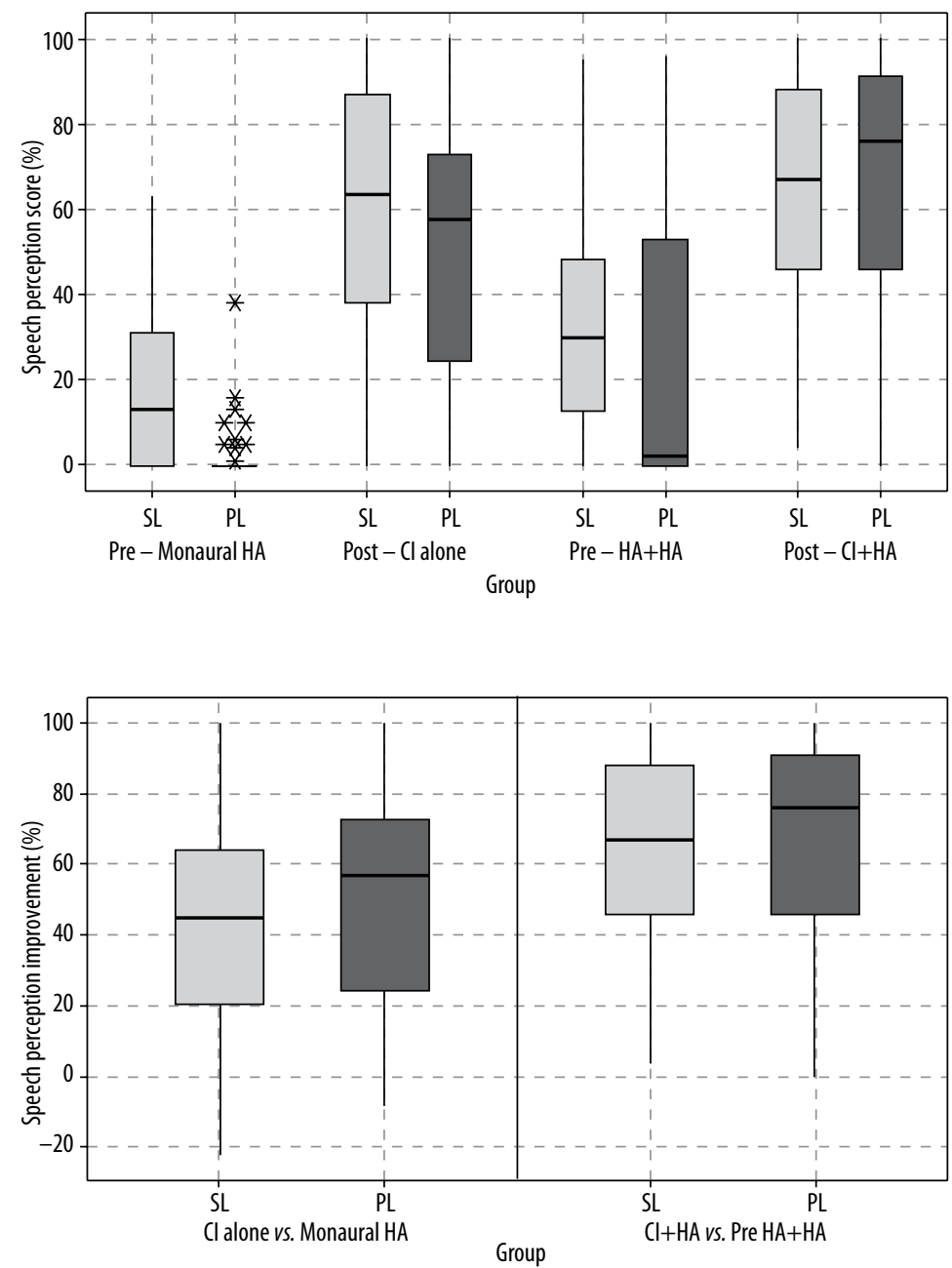

Figure 3. Comparison of the pre-implant and 3-month post-implant speech perception scores for the SL and PL groups. The left panel shows the pre- and postimplant monaural scores; the right panel shows the corresponding binaural scores. A significant difference is found between the pre-implant groups when speech perception is assessed via monaural hearing aids $(H A)$ - the SL group has significantly higher scores

Figure 4. Comparison of the percentage speech perception improvement for the $\mathrm{SL}$ and $\mathrm{PL}$ groups (measured by difference in scores at 3 months post-implant compared to pre-implant). The left panel shows the monaural improvement; the right panel shows the binaural improvement. There are no significant differences between the groups for either monaural or binaural improvement
The speech perception test battery included open set sentence and word testing using recorded material. City University of New York (CUNY) open set sentences were used, in which lists of 12 sentences were scored for the number of correctly identified words out of a total of approximately 102 keywords per sentence list. For each test, two sentence lists were presented and the average of the two scores was taken. CUNY sentence testing was conducted in quiet and in 8-talker babble background noise with a signal to noise ratio of $+10 \mathrm{~dB}$. In both the quiet and the noise test protocols, a female speaker was used. Open set monosyllabic word testing was conducted using consonant-nucleus-consonant (CNC) words, with lists of 50 words scored for the number of correctly identified words and phonemes, using a male speaker.

Recorded speech materials were used for all tests using a native Australian English speaker, presented sound track alone at $65 \mathrm{~dB}$ SPL. Appropriate masking was introduced to the contralateral ear where required. The masking procedure utilized a portable Sony digital media player (masker) to provide speech masking through insert phones, while the recipient listened to test materials from a loudspeaker via their hearing aid or cochlear implant sound processor. The masker continuously plays a wav file of broadband noise weighted according to the international long-term average speech spectrum (ILTASS) at a level calibrated to $75 \mathrm{~dB}$ SPL.

Pre-operative speech perception data was obtained during implant candidacy assessment with optimised hearing aids. Each patient's own hearing aids were verified in the clinic using real ear measures and compared to the target prescription. The NAL-NL1 and NAL-RP fitting algorithms were used to determine gain targets, with the choice of algorithm dependent on the configuration of the patient's audiogram $[29,30]$. Where a patient's hearing aids were not optimized for reasons other than documented loudness tolerance issues, they returned to their hearing aid provider for review of their aids prior to formal speech perception testing. Post-operative data was obtained at 3 and 12 months post CI activation, using the patient's CI sound processor and contralateral optimized hearing aid in the monaural (CI alone) and binaural (CI + HA) conditions. All speech perception results were obtained at the Melbourne Cochlear Implant Clinic.

To provide a more informative evaluation than assessing each test in the speech perception battery individually, an overall speech perception score was calculated by including each participant's result for each test in the analysis. 


\section{Surgery and devices}

The subjects in this study underwent surgery between September 2005 and July 2011. All patients received Contour Advance electrode arrays, being either Nucleus Freedom or Nucleus 5 CI512 devices. These devices are functionally identical, with slight cosmetic differences (refer to Cochlear Limited for details). In the SL group, 21 patients were fitted with the Nucleus Freedom cochlear implant, and 6 were fitted with the Nucleus 5 CI512 cochlear implant. In the PL group, 22 patients were fitted with the Nucleus Freedom, and 5 were fitted with the Nucleus 5 CI512. All participants used the Advanced Combination Encoder (ACE) sound coding strategy. Regarding stimulation rate, 20 recipients (74.1\%) from the SL group and 18 (66.7\%) from the PL group used the default of $900 \mathrm{~Hz}$. The remaining recipients from each group used a variety of stimulation rates from $250 \mathrm{~Hz}$ to $2400 \mathrm{~Hz}$ dependent on the recipient's personal preference.

\section{Statistics}

Statistical analysis was conducted using Minitab statistical software version 16 .

Paired $t$-tests were used in order to examine the difference between the population's pre- and post-operative speech perception scores, given that the samples were related and approached a normal distribution.

Additional data analysis was completed using nonparametric tests, as the data were not normally distributed. To assess the equality of group medians, Mood's median test was used in place of an analysis of variance. To examine the difference between two population medians, the MannWhitney test was used in place of a 2 -sample $t$-test. In order to investigate whether there was a relationship between two variables, Spearman rank correlation was used. An $\alpha$ level of 0.05 was used for all statistical tests.

\section{Results}

The results of this study demonstrate that the SL group had significantly better pre-implant speech perception scores compared with the PL group, and better post-implant scores looking at the implanted ear alone (Figure 3); however, in terms of pre- to post-operative improvement either for implanted ear alone or the bimodal condition, there were no significant differences shown between the groups (Figure 4). These results are discussed in further detail below.

\section{Demographics}

The groups demonstrated a high level of similarity with respect to duration of loss and age at implant. There were no significant differences found between the SL and PL matched groups for either duration of loss or age at implant ( $p=0.586$ and 0.414 respectively). As expected, due to the selection of the groups based on audiometric criteria, a significant difference was found between the groups in the four-frequency average $(\mathrm{dB})$ for both the ear to be implanted $(p<0.001)$ and the contralateral ear $(p<0.001)$. Refer to Table 1 for details of the median values for each comparison.
An analysis of the available data of the post-implant unaided hearing thresholds for the implanted ear was conducted. Of the SL group, 17 of the recipients had their post-implant hearing assessed (63\%), while only 7 of the recipients from the PL group had their post-implant hearing assessed (26\%). Mann-Whitney analysis of the group medians demonstrated no significant difference between the level of post-implant four-frequency average $(\mathrm{dB})$ in the SL and PL groups (SL median $122.5 \mathrm{~dB}$, PL median $123.8 \mathrm{~dB}, p=0.155$ ).

\section{Monaural analysis}

Paired $t$-test analysis showed the SL and the PL groups both demonstrated significantly higher speech perception scores measured at 3 months post-implant compared to their pre-implant scores when looking at the implanted ear alone (SL: $T=14.54, p<0.001$; PL: $T=15.91, p<0.001$ ).

The SL group demonstrated significantly better pre-implant speech perception scores compared to the PL group in the monaural condition for their ear to be implanted (SL median $=13.0 \%$, PL median $=0 \% ; p<0.001$ ).

At 3 months post-implant there was no significant difference in the speech perception scores between the groups in the $\mathrm{CI}$ alone condition, although it was noted that the SL group did tend towards higher scores (SL median $=63.5 \%$, PL median $=57.5 \%$; $p=0.119$ ).

The post-operative scores were compared to the pre-operative scores to examine whether either group received more benefit from the cochlear implant at the 3-month post-implant point. There were no significant differences between the groups for overall improvement in speech perception in the monaural condition (SL median improvement $45.0 \%$, PL median improvement 57.0\%; $p=0.342$ ).

Speech perception scores were also analysed at the 12-month post-implant point. At 12 months post-implant there was no significant difference in the speech perception scores between the groups in the CI alone condition, although it was again noted that the SL group did tend towards higher scores (SL median $=72.0 \%$, PL median $=66.5 \%$; $p=0.157$ ).

The 12-month post-operative scores were compared to the pre-operative scores to examine whether either group received more benefit from the cochlear implant at the later point. A significant difference was shown between the groups for overall improvement in speech perception in the monaural condition so that the PL group demonstrated greater improvement at 12 months (SL median improvement 44.0\%, PL median improvement 64.5\%; $p=0.047$ ).

Given the retrospective nature of this project, it must be noted that, as a limitation to the data at the 12 -month post-operative point, only $44-67 \%$ of the SL recipients completed the various speech perception tests and had data collected, compared with $70 \%$ of PL recipients who completed the speech perception battery. This limits the group matching and any conclusions that can be drawn at the 12-month point. 
Table 2. Correlation analysis for SL group

\begin{tabular}{|c|c|c|c|c|c|c|}
\hline SL group & $\begin{array}{l}\text { Duration of } \\
\text { deafness }\end{array}$ & Age at implant & $\begin{array}{l}\text { 4FA }(\mathrm{dB}) \text { - ear to } \\
\text { be implanted }\end{array}$ & $\begin{array}{c}\text { 4FA - } \\
\text { contralateral ear }\end{array}$ & $\begin{array}{l}\mathrm{Cl} \text { alone speech } \\
\text { perception } \\
(3 \mathrm{~m} \text { post })\end{array}$ & $\begin{array}{c}\mathrm{Cl}+\mathrm{HA} \text { speech } \\
\text { perception } \\
\text { ( } 3 \mathrm{~m} \text { post) }\end{array}$ \\
\hline $\begin{array}{l}\text { Duration of } \\
\text { deafness }\end{array}$ & & $\begin{array}{c}-0.342 \\
p<0.001\end{array}$ & $\begin{array}{c}0.159 \\
p=0.101\end{array}$ & $\begin{array}{c}0.251 \\
p=0.009\end{array}$ & $\begin{array}{c}-0.254 \\
p=0.011\end{array}$ & $\begin{array}{l}-0.130 \\
p=0.295\end{array}$ \\
\hline Age at implant & $\begin{array}{c}-0.342 \\
p<0.001\end{array}$ & & $\begin{array}{c}0.084 \\
p=0.387\end{array}$ & $\begin{array}{c}0.001 \\
p=0.992\end{array}$ & $\begin{array}{c}-0.234 \\
p=0.021\end{array}$ & $\begin{array}{c}-0.273 \\
p=0.025\end{array}$ \\
\hline $\begin{array}{l}\text { 4FA }(\mathrm{dB}) \text { - ear to } \\
\text { be implanted }\end{array}$ & $\begin{array}{c}0.159 \\
p=0.101\end{array}$ & $\begin{array}{c}0.084 \\
p=0.387\end{array}$ & & $\begin{array}{c}0.462 \\
p=<0.001\end{array}$ & $\begin{array}{c}0.079 \\
p=0.438\end{array}$ & $\begin{array}{c}0.102 \\
p=0.413\end{array}$ \\
\hline $\begin{array}{l}\text { 4FA - } \\
\text { contralateral ear }\end{array}$ & $\begin{array}{c}0.251 \\
p=0.009\end{array}$ & $\begin{array}{c}0.001 \\
p=0.992\end{array}$ & $\begin{array}{c}0.462 \\
p \leq 0.001\end{array}$ & & $\begin{array}{l}-0.169 \\
p=0.097\end{array}$ & $\begin{array}{c}-0.263 \\
p=0.032\end{array}$ \\
\hline $\begin{array}{l}\mathrm{Cl} \text { alone speech } \\
\text { perception } \\
\text { ( } 3 \text { m post) }\end{array}$ & $\begin{array}{c}-0.254 \\
p=0.011\end{array}$ & $\begin{array}{c}-0.234 \\
p=0.021\end{array}$ & $\begin{array}{c}0.079 \\
p=0.438\end{array}$ & $\begin{array}{c}-0.169 \\
p=0.097\end{array}$ & & $\begin{array}{c}0.883 \\
p<0.001\end{array}$ \\
\hline $\begin{array}{l}\mathrm{Cl}+\mathrm{HA} \text { speech } \\
\text { perception } \\
\text { ( } 3 \text { m post) }\end{array}$ & $\begin{array}{c}-0.130 \\
p=0.295\end{array}$ & $\begin{array}{c}-0.273 \\
p=0.025\end{array}$ & $\begin{array}{c}0.102 \\
p=0.413\end{array}$ & $\begin{array}{c}-0.263 \\
p=0.032\end{array}$ & $\begin{array}{c}0.883 \\
p<0.001\end{array}$ & \\
\hline
\end{tabular}

Table 3. Correlation analysis for PL group

\begin{tabular}{|c|c|c|c|c|c|c|}
\hline PL group & $\begin{array}{l}\text { Duration of } \\
\text { deafness }\end{array}$ & Age at implant & $\begin{array}{l}\text { 4FA }(\mathrm{dB}) \text { - ear to } \\
\text { be implanted }\end{array}$ & $\begin{array}{c}\text { 4FA - } \\
\text { contralateral ear }\end{array}$ & $\begin{array}{l}\mathrm{Cl} \text { alone speech } \\
\text { perception } \\
\text { (3 m post) }\end{array}$ & $\begin{array}{c}\mathrm{Cl}+\mathrm{HA} \text { speech } \\
\text { perception } \\
\text { (3 m post) }\end{array}$ \\
\hline $\begin{array}{l}\text { Duration of } \\
\text { deafness }\end{array}$ & & $\begin{array}{c}-0.239 \\
p=0.013\end{array}$ & $\begin{array}{c}0.511 \\
p<0.001\end{array}$ & $\begin{array}{c}-0.319 \\
p=0.001\end{array}$ & $\begin{array}{c}0.020 \\
p=0.840\end{array}$ & $\begin{array}{c}0.234 \\
p=0.106\end{array}$ \\
\hline Age at implant & $\begin{array}{c}-0.239 \\
p=0.013\end{array}$ & & $\begin{array}{c}-0.256 \\
p=0.007\end{array}$ & $\begin{array}{c}0.249 \\
p=0.009\end{array}$ & $\begin{array}{l}-0.145 \\
p=0.149\end{array}$ & $\begin{array}{c}0.107 \\
p=0.465\end{array}$ \\
\hline $\begin{array}{l}\text { 4FA }(d B)-\text { ear to } \\
\text { be implanted }\end{array}$ & $\begin{array}{c}0.511 \\
p<0.001\end{array}$ & $\begin{array}{c}-0.256 \\
p=0.007\end{array}$ & & $\begin{array}{l}-0.181 \\
p=0.061\end{array}$ & $\begin{array}{c}0.083 \\
p=0.413\end{array}$ & $\begin{array}{c}0.363 \\
p=0.010\end{array}$ \\
\hline $\begin{array}{l}\text { 4FA - } \\
\text { contralateral ear }\end{array}$ & $\begin{array}{c}-0.319 \\
p=0.001\end{array}$ & $\begin{array}{c}0.249 \\
p=0.009\end{array}$ & $\begin{array}{l}-0.181 \\
p=0.061\end{array}$ & & $\begin{array}{c}0.023 \\
p=0.822\end{array}$ & $\begin{array}{l}-0.106 \\
p=0.467\end{array}$ \\
\hline $\begin{array}{l}\mathrm{Cl} \text { alone speech } \\
\text { perception } \\
(3 \mathrm{~m} \text { post })\end{array}$ & $\begin{array}{c}0.020 \\
p=0.840\end{array}$ & $\begin{array}{l}-0.145 \\
p=0.149\end{array}$ & $\begin{array}{c}0.083 \\
p=0.413\end{array}$ & $\begin{array}{c}0.023 \\
p=0.822\end{array}$ & & $\begin{array}{c}0.652 \\
p<0.001\end{array}$ \\
\hline $\begin{array}{l}\mathrm{Cl}+\mathrm{HA} \text { speech } \\
\text { perception } \\
(3 \mathrm{~m} \text { post) }\end{array}$ & $\begin{array}{c}0.234 \\
p=0.106\end{array}$ & $\begin{array}{c}0.107 \\
p=0.465\end{array}$ & $\begin{array}{c}0.363 \\
p=0.010\end{array}$ & $\begin{array}{c}-0.106 \\
p=0.467\end{array}$ & $\begin{array}{c}0.652 \\
p<0.001\end{array}$ & \\
\hline
\end{tabular}

Binaural analysis

Paired $t$-test analysis showed that the SL and the PL groups both demonstrated significantly higher speech perception scores measured at 3 months post-implant compared to their pre-implant scores in the binaural condition (SL: $T=8.26, p<0.001$; PL: $T=6.27, p<0.001$ ).

The SL group demonstrated significantly better pre-implant speech perception scores compared to the PL group in the binaural condition using their optimized hearing aids (SL median $=30.0$, PL median $=2.0 ; p=0.008$ ).

Examining the post-implant results for the binaural $(\mathrm{CI}+\mathrm{HA})$ condition, it was found that there was no significant difference in the speech perception scores between the groups measured at 3 months post-op (SL median $=67.0 \%$, PL median $=76.0 \% ; p=0.378$ ).
The post-operative $\mathrm{CI}+\mathrm{HA}$ scores were compared to the pre-operative HA+HA scores to examine whether either group received more benefit from the cochlear implant at the 3-month post-implant point. There were no significant differences between the groups for overall improvement in speech perception in the binaural condition (SL median improvement $30.0 \%$, PL median improvement $24.0 \% ; p=0.413)$.

There were no data collected in the CI+HA condition at 12 months post-implant.

\section{Correlation analysis}

Correlation analyses were performed to assess whether the speech perception outcomes of the SL and PL groups were associated with established predictive factors. Details of these correlation analyses are provided in Tables 2 and 3. Significant weak negative correlations were found for the SL group between age at implant and both CI alone 
and $\mathrm{CI}+\mathrm{HA}$ speech perception at 3 months post-implant. Duration of deafness was also found to have a significant weak negative correlation with CI alone speech perception in the SL group only. A significant correlation was found between pre-op 4FA $(\mathrm{dB})$ in the ear to be implanted and CI+HA speech perception at 3 months for the PL group only. Finally, significant weak negative correlations were found between age at implant and duration of deafness for both the SL and the PL groups.

\section{Discussion}

The over-arching aim of this study was to compare the outcomes for postlingually deafened adults with sloping hearing loss (who were implanted with standard-length electrode arrays without an attempt at hearing preservation) with outcomes from hybrid stimulation; the comparison was also made with a matched group of adults with profound hearing loss who had been clear candidates for cochlear implantation. The underlying concept of this analysis was to examine the speech perception benefits available to recipients with pre-operative residual hearing, or SL, in a situation where all residual hearing was lost. The results of such an analysis can provide CI clinicians with information that can be used to counsel patients who risk their pre-operative low frequency hearing by proceeding with implantation in today's clinical setting. The results demonstrated that cochlear implantation can provide significant benefit to adults with pre-operative SL, and the SL group can obtain equivalent levels of benefit to their implanted peers who had profound hearing loss.

The results of this study support the findings of Incerti et al. [22] who demonstrated that recipients achieved significantly better post-operative speech perception scores (compared to pre-operative) using only the electric component of their EAS system. In the present study, hearing preservation techniques were not used and the recipients in the SL group did not use an EAS configuration; however, performance on speech perception tests was equivalent to their peers in the PL group, and the SL group did indeed demonstrate significantly better scores post-operatively compared to their pre-operative scores.

A major issue facing clinicians and patients today is the risk of losing natural residual hearing following cochlear implantation with a hearing preservation technique, and whether the patient will be worse off in that instance. In a systematic review of 187 publications on EAS using both Nucleus and Med-El devices and assessing a variety of outcomes including hearing preservation, Talbot and Hartley [31] found that $24 \%$ of recipients experienced greater than $20 \mathrm{~dB}$ hearing loss across all frequencies. The results of this study suggest that an SL patient with poor pre-operative speech perception is likely to have an equivalent level of improvement to a more typical CI patient, even if they lose all residual hearing. Should the patient retain their natural hearing after the CI procedure, we can expect their performance to be superior based on the reported benefits of EAS.

Previous studies have demonstrated that, for adults using cochlear implants, duration of deafness, age at implant, and pre-operative speech perception are factors that have a significant effect on outcomes [32-35]. In the present study, significant weak negative correlations were found between the speech perception outcomes of the SL group and age at implant (that is, older patients performed slightly poorer). The PL group demonstrated significantly better binaural speech perception with a higher pre-operative 4FA in the implanted ear. In both groups, a significant weak negative correlation was found between age at implant and duration of deafness, indicating that the individuals in the group implanted younger had been deaf longer and waited longer for their implant.

Additionally, a weak negative correlation was found in the SL group between speech perception and duration of deafness, although this is contrary to what previous studies have found. There may be a number of reasons for this. Firstly, the number of participants in the SL group in this study was relatively small at 27 compared to the large group analyses noted previously [32,35]. A follow-up study with increased subject numbers may clarify this result. In addition, the question of 'duration of deafness' is problematic in the SL group, given that they were technically using some natural low frequency hearing up to the point of cochlear implantation. Since duration of deafness is illdefined in this group, this may have also contributed to an unusual correlation result. Finally, previous studies have noted that there is a relatively large amount of variability in outcomes that can not be accounted for by known predictive factors or pre-operative assessments [33], and this was evident in this population of recipients who had significant pre-operative residual hearing.

Patients with SL are presenting more regularly to cochlear implant centres, and they bring with them additional challenges in making treatment recommendations. Given their residual hearing, patients with SL may present with speech perception abilities that render them, under traditional guidelines, 'borderline' candidates.

Particular attention must be paid to the level of residual hearing this group of SL patients had prior to cochlear implantation. As discussed previously, despite this group having significant low tone hearing they were selected for standard Contour electrode arrays as their preoperative speech perception was relatively poor. Additionally, given their hearing configuration, the available electrode choice, and the clinical criterion for short-electrode insertion at the time, no attempt was made to provide the SL group with electro-acoustic stimulation. It should be noted that in today's clinical setting use of newer electrode arrays specifically designed for preservation of residual acoustic hearing (e.g. Nucleus CI422, Med-El Flex28) may give patients with SL better chances of preserving and making use of their natural low frequency hearing and take advantage of EAS. Skarzynski et al. [36] have demonstrated high levels of hearing preservation in patients with pre-operative residual hearing when using full-length electrode arrays with deep insertion and surgical techniques designed to minimise electrode insertion trauma. The evolution of devices and surgical techniques provides an opportunity for more recipients to benefit from acoustic stimulation in combination with their CI. Turner et al. [14] highlighted the benefits of integrating electrical and acoustic hearing in patients implanted with the Iowa/Nucleus Hybrid device: the participants with the electroacoustic hearing had improved 
speech recognition in competing noise compared to participants using traditional cochlear implants. The authors attributed this difference to the preservation of low frequency hearing in the participants using the electroacoustic device. In these cases, the authors postulated that participants with preserved natural low frequency hearing would in turn have preserved outer hair cell tuning curves, leading to increased frequency resolution [14]. In contrast, a recent publication by Cosetti [37] demonstrated that while hearing could be preserved using conventional Contour implants, there was no correlation between hearing preservation and performance on speech perception tasks. The benefits of low frequency hearing preservation have been found in areas other than speech perception, such as in improved frequency resolution which has also been found to improve music perception and appreciation in implant recipients with electroacoustic hearing [38,39]. Incerti [22] reviewed hearing and speech perception outcomes and fitting techniques across patients implanted with standard perimodiolar electrode arrays, standard- to medium-length straight arrays, and electroacoustic arrays. This study highlighted the variety of devices available for use today in patients with pre-operative low frequency hearing, and the excellent hearing preservation that has been demonstrated in the literature with available electrode arrays.

\section{Conclusions}

The results of this study demonstrate that postlingually deafened adults with sloping hearing loss have the potential to gain significant benefit from electrical stimulation, and can achieve equivalent levels of improvement to typical candidates with profound hearing loss. The results presented in this paper provide evidence to support the preoperative clinical counseling of patients with residual hearing. Patients with SL can be counseled that, should they lose their residual natural hearing because of the operation, they are still likely to gain a significant benefit from their cochlear implant. Should the patient retain their low frequency residual hearing, research suggests their outcome could only be further improved in terms of sound quality, naturalness, and music perception. The results suggest that clinics should consider recommending cochlear implantation for patients with sloping hearing loss in cases where conventional amplification fails to offer sufficient speech perception benefit and the patient is motivated to seek other options. When considering the proven benefits of EAS, the results of this study support the combination of a hearing preservation approach using a full-length electrode in patients with sloping hearing loss. Further research with larger numbers is required to assess the outcomes for adults with sloping hearing loss who receive CIs designed for hearing preservation.

\section{Acknowledgements}

The authors thank staff at the Melbourne Cochlear Implant Clinic, both past and present, whose contribution to research and data collection is invaluable in enabling projects like this to be completed.

\section{References:}

1. Miller GA, Nicely PE. An analysis of perceptual confusions among some English consonants. J Acoust Soc Am, 1955; 27(2): $338-52$.

2. Turner CW. Hearing loss and the limits of amplification. Audiol Neurootol, 2006; 11(Suppl.1): 2-5.

3. Moore BC. Dead regions in the cochlea: diagnosis, perceptual consequences, and the implications for the fitting of hearing aids. Trends Amplif, 2001; 5(1): 1-34

4. Vinay, Moore BC. Prevalence of dead regions in subjects with sensorineural hearing loss. Ear Hear, 2007; 28(2): 231-41.

5. Moore BC. Dead regions in the cochlea: conceptual foundations, diagnosis, and clinical applications. Ear Hear, 2004; 25(2): 98-116.

6. Hogan CA, Turner CW. High-frequency audibility: benefits for hearing-impaired listeners. J Acoust Soc Am, 1998; 104(1): $432-41$.

7. Turner CW, Cummings KJ. Speech audibility for listeners with high-frequency hearing loss. Am J Audiol, 1999; 8(1): 47-56.

8. Ching TY, Dillon H, Byrne D. Speech recognition of hearingimpaired listeners: predictions from audibility and the limited role of high-frequency amplification. J Acoust Soc Am, 1998; 103(2): 1128-40.

9. Glista D, Scollie S, Bagatto M, Seewald R, Parsa V, Johnson A. Evaluation of nonlinear frequency compression: clinical outcomes. Int J Audiol, 2009; 48(9): 632-44.

10. Simpson A, McDermott HJ, Dowell RC. Benefits of audibility for listeners with severe high-frequency hearing loss. Hearing Res, 2005; 210(1-2): 42-52.
11. Simpson A, Hersbach AA, McDermott HJ. Frequency-compression outcomes in listeners with steeply sloping audiograms. Int J Audiol, 2006; 45(11): 619-29.

12. Kuk F, Keenan D, Korhonen P, Lau CC. Efficacy of linear frequency transposition on consonant identification in quiet and in noise. J Am Acad Audiol, 2009; 20(8): 465-79.

13. Buchner A, Schussler M, Battmer RD, Stover T, Lesinski-Schiedat A, Lenarz T. Impact of low-frequency hearing. Audiol Neurootol, 2009; 14(Suppl.1): 8-13.

14. Turner CW, Gantz BJ, Reiss L: Integration of acoustic and electrical hearing. J Rehabil Res Dev, 2008; 45(5): 769-78.

15. Woodson EA, Reiss LA, Turner CW, Gfeller K, Gantz BJ. The Hybrid cochlear implant: a review. Adv Otorhinolaryngol, 2010; 67: 125-34.

16. Gstoettner WK, van de Heyning P, O'Connor AF, Morera C, Sainz M, Vermeire K et al. Electric acoustic stimulation of the auditory system: results of a multi-centre investigation. Acta Otolaryngol, 2008; 128(9): 968-75.

17. Briggs RJ, Tykocinski M, Xu J, Risi F, Svehla M, Cowan R et al. Comparison of round window and cochleostomy approaches with a prototype hearing preservation electrode. Audiol Neurootol, 2006; 11(Suppl.1: 42-8.

18. Gstoettner W, Helbig S, Settevendemie C, Baumann U, Wagenblast J, Arnoldner C. A new electrode for residual hearing preservation in cochlear implantation: first clinical results. Acta Otolaryngol, 2009; 129(4): 372-9.

19. von Ilberg CA, Baumann U, Kiefer J, Tillein J, Adunka OF. Electric-acoustic stimulation of the auditory system: a review of the first decade. Audiol Neurootol, 2011; 16(Suppl.2): 1-30. 
20. Kiefer J, Pok M, Adunka O et al. Combined electric and acoustic stimulation of the auditory system: results of a clinical study. Audiol Neurootol, 2005; 10(3): 134-44.

21. Simpson A, McDermott HJ, Dowell RC, Sucher C, Briggs RJS Comparison of two frequency-to-electrode maps for acousticelectric stimulation. Int J Audiol, 2009; 48(2): 63-73.

22. Incerti PV, Ching TY, Cowan R. A systematic review of electric-acoustic stimulation: device fitting ranges, outcomes and clinical fitting practices. Trends Amplif, 2013; 17(1): 3-26

23. Helbig S, Baumann U, Helbig M, von Malsen-Waldkirch N, Gstoettner W. A new combined speech processor for electric and acoustic stimulation: eight months experience. ORL J Otorhinolaryngol Rela Spec, 2008; 70(6): 359-65.

24. Skarzynski H, Lorens A, Matusiak M, Porowski M, Skarzynski PH, James CJ. Partial deafness treatment with the Nucleus straight research array cochlear implant. Audiol Neurootol, 2012; 17(2): 82-91.

25. Jayawardena J, Kuthubutheen J, Rajan G. Hearing preservation and hearing improvement after reimplantation of pediatric and adult patients with partial deafness: a retrospective case series review. Otol Neurotol, 2012; 33(5): 740-4.

26. Leigh J, Hollow R, Winton E, Tari S, Dowell RC. A further update of the recommendation guidelines for cochlear implantation. Audiology Australia XIX National Conference; May 2010; Sydney, Australia 2010.

27. Gifford RH, Dorman MF, Shallop JK, Sydlowski SA. Evidence for the expansion of adult cochlear implant candidacy. Ear Hear, 2010; 31(2): 186-94.

28. Dowell RC. Evaluating cochlear implant candidacy: recent developments. Hear J, 2005; 58(11): 9-23.

29. Byrne D, Dillon H. The National Acoustic Laboratories' (NAL) new procedure for selecting the gain and frequency response of a hearing aid. Ear Hear, 1986; 7(4): 257-65.

30. Dillon H. NAL-NL1: A new procedure for fitting non-linear hearing aids. Hear J, 1999; 52(4): 12-6.
31. Talbot KN, Hartley DE. Combined electro-acoustic stimulation: a beneficial union? Clin Otolaryngol, 2008; 33(6): 536-45.

32. Blamey P, Arndt P, Bergeron F, Bredberg G, Brimacombe J, Facer $\mathrm{G}$ et al. Factors affecting auditory performance of postlinguistically deaf adults using cochlear implants. Audiol Neurootol, 1996; 1(5): 293-306.

33. Dowell RC, Hollow R, Winton E. Outcomes for cochlear implant users with significant residual hearing: implications for selection criteria in children. Arch Otolaryngol Head Neck Surg, 2004; 130(5): 575-81.

34. Dowell RC. Evidence about the effectiveness of cochlear implants for adults. In: Wong L, Hickson L (eds.), Evidence-Based Practice in Audiology: Evaluating Interventions for Children and Adults with Hearing Implairment. $1^{\text {st }}$ ed: Plural Publishing; 2012; 141-65.

35. Blamey P, Artieres F, Baskent D, Bergeron F, Beynon A, Burke E et al. Factors affecting auditory performance of postlinguistically deaf adults using cochlear implants: an update with 2251 patients. Audiol Neurootol, 2013; 18(1): 36-47.

36. Skarzynski H, Lorens A, Zgoda M, Piotrowska A, Skarzynski PH, Szkielkowska A. Atraumatic round window deep insertion of cochlear electrodes. Acta Otolaryngol, 2011; 131(7): $740-9$.

37. Cosetti MK1, Friedmann DR, Zhu BZ, Heman-Ackah SE, Fang $\mathrm{Y}$, Keller RG et al. The effects of residual hearing in traditional cochlear implant candidates after implantation with a conventional electrode. Otol Neurotol, 2013; 34(3): 516-21

38. Gfeller K, Olszewski C, Turner C, Gantz B, Oleson J. Music perception with cochlear implants and residual hearing. Audiol Neurootol, 2006; 11(Suppl.1): 12-5.

39. Sucher CM, McDermott HJ. Bimodal stimulation: benefits for music perception and sound quality. Cochlear Implants Int, 2009; 10(Suppl.1): 96-9. 